\title{
Rahmatan Lil Alamin, the Concept of Multicultural Education
}

\author{
Ahmad Fathoni Rodli \\ Universitas Maarif Hasyim Latif, Sidoarjo, Indonesia \\ \{fathoni rodli@dosen.umaha.ac.id\}
}

\begin{abstract}
Indonesia is a country consisting of different peoples such as religion, tribe, race, culture, customs, language, etc. make Indonesian society as a plural society. In this diverse life, it is a challenge to unite the Indonesian nation into a force that can uphold the diversity and diversity of its people. This can be done with a multicultural education that is invested in the student through learning at college. This article explores patterns of multicultural education at Universitas Maarif Hasim Latif Sidoarjo in East Java. A lecturer is responsible for providing training to their students and assisted by society in seeing the differences that occur in their daily lives that promote the importance of tolerance in diversity making Indonesians accept that they live in variety. Finally, this paper figure out the multicultural education processes establish since the preparation of curriculum, learning and evaluation processes. These three processes are implemented in formal and informal learning processes.
\end{abstract}

Keywords: Rahmatan Lil 'Alamin, Concept, Multicultural, UMAHA Sidoarjo, Cultivation.

\section{Introduction}

Indonesia is a country of various ethnic, cultural, and religious groups that can simply be called a multicultural society. On the other hand, however, the multicultural reality confronts the urgent need to reconstruct the Indonesian national culture which can be an integrating force that binds the entire ethnic and cultural diversity. Pluralism must be found in every community.

Indonesia has tribal pluralism. The plurality of this tribe is one of the characteristics of Indonesian society that can be proud of. However, without we realize that the plurality also holds the potential conflicts that can threaten the life of the nation and state. This has been proven in some areas of Indonesian conflict.

Education is essentially a unifying tool of the nation, equality of opportunity, and the development of the self-potential to the fullest. Therefore, education is expected to minimize the differences of the citizens, rich and poor, men or women are all gettingequal opportunities to develop their potential optimally. But in reality, education is still not able to make it happen. However, real education is the education which can recognize, to accommodate all possibilities, to understand the heterogeneity, to respect the differences of tribes, nations, and religions. 
The multicultural values are an important value to be applied in the higher education environment, the universities are the social life miniatures of Indonesian people as pluralistic in term of race, gender, ethnicity, religion and social life[1]. Furthermore, the empirical facts indicate that this nation is multicultural nation, [2] the differences will always continue between the existing cultural entities to be in more attractive based on their tendencies and interests. If the cultural relationship between those citizens with the different cultural backgrounds are not maintained, then it can lead to the disharmony of the citizens' relation.

That is why multicultural education is worthy of being introduced. The multiculturalism education emerged as a solution to society's dissatisfaction with the education system that has been implemented. The multiculturalism education has a philosophical foundation that accommodates the gaps in education, culture, and religion. These three things have an interrelated orientation that leads to humanity. This is in line with one of the multicultural education orientations of humanity.

The educational institutions especially the Islamic universities, are one of the educational institutions which have the responsibility and a strategic role in developing a multiculturaloriented Islamic education. This is because the Islamic universities print and produce the Muslim scholars.

So does Maarif Hasim Latif University which will print and produce the professional and competent Muslim academics. Also, the students in UMAHA Sidoarjo mostly come from pesantren, one form of the educational institutions which are closely emotional and cultural with the grassroots community. It is expected with a multicultural education that the learners later can take part in a pluralist society.

In a descriptive context, the multicultural education should contain themes on tolerance, ethnocultural and religious differences, the danger of discrimination, conflict resolution and mediation, human rights, plurality, universal humanity and other relevant subjects[3].

\section{Literature review}

Education in a multicultural insight in James A. Bank's formulation is a concept, idea or philosophy which is as a belief or explanation that recognize and value the importance of cultural and ethnic diversity in shaping lifestyle, social experience, and personal identity, educational opportunities of the individual, group and countries[4].

According to Sonia Nieto, multicultural education is a comprehensive and fundamental education process for all learners. This type of education opposes all forms of racism and discrimination in schools and communities by accepting the plurality that is reflected among learners, among their communities, and teachers. According to Sonia, the multicultural education must be inherent in the curriculum and teaching strategies, including in every interaction among teachers, students,and families as well as the overall teaching and learning atmosphere. This type of education is a critical, reflective pedagogy and a basis for changing the action in society; thenmulticultural education develops the principle of democracy in social justice[5].

In his paper entitled "Multicultural Awareness: A Movement of "Interest Minimalization" in Reducing Social Conflict" which was introduced in Multicultural Education book by M. Ainul Yaqin[6].Prof. Dr. H.M. Amin Abdullah explains broadly the discourse of the multiculturalism to understand the differences which are naturally and inherently exist in human beings and how then the differences can be understood and accepted as natural so as not to cause the discriminatory action as a result of the life patterns and behaviors that reflect jealousy heart, spite, and bad thought[7]. 
Meanwhile, Bikhu Parekh defines the multicultural education as "an education in freedom, both in the sense of freedom from ethnocentric prejudices and beasts, and freedom to explore and learn from other cultures and perspectives"[8].

The application of multicultural values in universities is expected that the learning process will not only make the students have many good skills and understanding in the course they are studied, but also have a good understanding related to the value application of pluralism, humanism, and democracy in the daily[8].

From the description above, there are many important things in the multicultural discourse in education that is identity, openness, cultural diversity and social transformation. Identity as one element in education which assumes that the learners and teachers are an individual or group representing a particular culture in society.

Concerning to the focus of multicultural education, H.A.R. Tilaar [9]reveals that in a multicultural education program, the focus is no longer directed solely to the mainstream social, religious and cultural groups. Multicultural education is a caring and understanding attitude or acknowledgment of other people. In that context, multicultural education sees the society more broadly. Based on the basic view that the attitude of indifference and nonrecognition is not only rooted in the racial inequalitystructure but the paradigm.

\section{Method}

The researcher uses qualitative descriptive research methods. This research method is used because the researcher will conduct the field research directly to find out what kind of multicultural values application in UMAHA Sidoarjo and how the impact on students. Qualitative descriptive method is a suitable used in this research.[10]

This research utilizes qualitative with the "dominant less" design prevailingstructure, "and research inquires about plan what's more, advancement $(R$ and $D)[11]$. The examination was led in three phases: (1) Preliminary Study (Investigation contemplate) (2) Model advancement (Classroom Action Research) and (3) Testing (exploratory investigation) that utilizes semi test. Area assurance in one collegein Sidoarjo City, UMAHA was controlled by purposive examining.

Information types are essential and auxiliary information. Respondents and key witnesses of the investigation arespeakers, understudies, think about projects and network pioneers who can give data about the issue under investigation. Information gathering done by the strategy for documentation, perception, talk with, survey/poll (test). Information investigation was done by blending strategy, which is unmistakable Subjectively joined with elucidating quantitative straightforward (rate and recurrence appropriation) also, t-test and f test utilizing the SPSS program.

\section{Results and discussion}

Universitas Maarif Hasyim Latif (UMAHA) Sidoarjo demonstrated his quality as a private school national dimension. Expanded fundamentally bring UMAHA just inside a time of three years. As occurred as of now, the accomplishment bounced 404 positions to the national dimension. In the earlier year, positioning UMAHA still in position to 808. Hence, UMAHA dependably rouses the whole scholastic network to keep on enhancing themselves in their particular fields of mastery. As the network administration exercises prior to the strengthening of the waterway. UMAHA endeavors in keeping up and enhancing the quality, scope of 
projects, for example, this that has been begun by working with the University of Thailand in the sit-in program. It is normal that later on, UMAHA can keep on enhancing ourselves from all viewpoints, enhance scholastic notoriety, particularly in the examination advancement[12].

Based on the observation data, interviews, and in-depth study of several documents related to the academic and social potency of UMAHA students, the author concludes as follows.

Multicultural material development based on local wisdom in higher education refers to the idea that Citizenship Education for Indonesia, philosophically and substantivelypedagogically demagogically, is education to facilitate the personal development of students to become Indonesian citizens who are religious, civilized, have the spirit of Indonesian unity, democratic and responsible, and just, and able to live harmoniously in the context of multiculturalism - Bhinneka Tunggal Ika.

Based on the above thoughts, the standard competencies that will be produced in the development of Multicultural material based on local wisdom in this university are: "Equip students to become citizens who are able to coexist with other citizens without distinguishing their religion, race, language and culture and being able to develop the nation becomes a great nation that is respected and respected internationally. "

The Standard Competencies in the learning practices are then developed in detail into 5 (five) basic competencies which include: (a) Being citizens who accept ethnic, religious, linguistic and cultural differences in the structure of their society (local wisdom base); (b) Become a citizen who can collaborate in multi-ethnic, multi-cultural, multi-religious ways in the context of the development of the nation's economy and strength; (c) Becoming citizens who are able to respect the individual rights of citizens without distinguishing ethnic, religious, linguistic and cultural backgrounds in all social, educational, economic, political sectors even to monasticism the language and develop their culture; (d) Becoming citizens who provide opportunities for all citizens to represent their ideas and aspirations in government institutions, both legislative and executive; and (e) Become citizens who can develop a fair attitude and develop a sense of justice for all citizens regardless of their ethnic, religious, linguistic and cultural backgrounds. Then based on the Decree of the Director General of Higher Education No. 38 / Dikti / 2002 [13] concerning Significant Signals reinforces the finding that this lecture can develop students' multicultural citizenship competencies in Higher Education in any category. At the model testing stage, there also appears to be aspects of student learning motivation from the comparison of the results of the average score of the experimental class group higher than the control group with $(\mathrm{F}=7.106$ with a significantly smaller than 0.05$)$. Based on the findings above, it can also be concluded that students in the experimental class group in the Sidoarjo College of Education felt that learning motivation increased higher than before.

In addition, the instructional impact in the Multicultural learning model based on local wisdom with social inquiry is: (a) able to research social problems and (b) be able to develop responsibility for community improvement as a form of commitment to improving the quality of citizens (c) can develop student multicultural citizenship competency. The impact of accompaniment in this learning are: (a) the emergence of respect and respect for the dignity of others and being more tolerant (tolerance in dialogue) among students, (b) habits of social / multicultural behaviour in the community and (c) Motivation for learning and achieving students in lectures increases[14].

As a form of commitment to the development of the multicultural values which has been the hallmark of UMAHA for a long time and realized in the form of policy and academic activities, then established the Center for Study of the task to ensure a culture of multicultural in the frame of "Rahmatan lil "alamin" in providing service to a student and sociality. 
After the establishment of the Study Center can be implemented, then the programs related to the guarantee and facilitation are continuously developed and implemented.

\section{Conclusion}

Based on the above description, it can be concluded that the impact of the development and application of multicultural values in UMAHA to the social and academic life is very real which is able to assist the efforts to improve the academic ability and students social activities.

\section{References}

[1] A. M. Anam, "Penanaman nilai-nilaipendidikanmultikultural di perguruantinggi: Studi kasus di Universitas Islam Malang," Universitas Islam Negeri Maulana Malik Ibrahim, 2016.

[2] R. Schefold, "The domestication of culture: Nation-building and ethnic diversity in Indonesia," Bijdr. tot Taal-, Land-en Volkenkd., vol. 154, no. 2, pp. 259-280, 1998.

[3] M. L. Fernandez and M. Robinson, "Prospective teachers' perspectives on microteaching lesson study," Education, vol. 127, no. 2, pp. 203-216, 2006.

[4] J. A. Banks and C. A. M. Banks, Handbook of research on multicultural education. New York: Macmillan Publishing, 2004.

[5] S. Nieto, Affirming diversity: The sociopolitical context of multicultural education. New York: Longman, 1992.

[6] M. A. Yaqin, Pendidikan multikultural: cross-cultural understanding untukdemokrasi dan keadilan. Pilar Media, 2005.

[7] M. A. Abdullah, "Kesadaran Multikultural: Sebuah Gerakan 'Interest Minimalization'dalam Meredakan Konflik Sosial," in Pendidikan Multikultural, M. A. Yaqin, Ed. Yogyakarta: Pilar, 2006.

[8] B. Parekh, "Rethinking multiculturalism: Cultural diversity and political theory," Ethnicities, vol. 1, no. 1, pp. 109-115, 2001.

[9] H. A. R. Tilaar, Multicultural Education and ITS Challengers in Indonesia. Jakarta: Penerbit Buku Kompas, 2005.

[10] C. Marshall and G. B. Rossman, Designing qualitative research. Thousand Oaks: Sage publications, 2014.

[11] J. Ritchie, J. Lewis, C. M. Nicholls, and R. Ormston, Qualitative research practice: A guide for social science students and researchers. New Jersey: Sage Publication, 2013.

[12] E. Setyawan, "Rangking UMAHA Naik Tiap Tahun," Universitas Maarif Hasyim Latif, $2017 . \quad$ [Online]. Available: http://international.umaha.ac.id/index.php/2017/12/04/rangking-umaha-naik-tiaptahun/.

[13] C. S. T. Kansil and C. S. T. Kansil, Pendidikan kewarganegaraan di perguruan tinggi: berdasarkan keputusan Dirjen Pendidikan Tinggi No. 38/DIKTI/Kep./2002. Jakarta: Pradnya Paramita, 2003.

[14] A. F. Rodli, A. Prasnowo, M. B. N. Wajdi, and S. Sajiyo, "Building a Culture of Learning to Accelerate the Advancement of Higher Learning," in International Conference on Religion and Public Civilization (ICRPC 2018), 2018. 